\title{
Investigating organic aerosol loading in the remote marine environment
}

\author{
K. Lapina ${ }^{1}$, C. L. Heald ${ }^{1}$, D. V. Spracklen ${ }^{2}$, S. R. Arnold ${ }^{2}$, J. D. Allan ${ }^{3}$, H. Coe ${ }^{3}$, G. McFiggans ${ }^{3}$, S. R. Zorn ${ }^{4, *}$, \\ F. Drewnick ${ }^{4}$, T. S. Bates ${ }^{5}$, L. N. Hawkins ${ }^{6}$, L. M. Russell ${ }^{6}$, A. Smirnov ${ }^{7}$, C. D. O'Dowd ${ }^{8}$, and A. J. Hind ${ }^{9}$ \\ ${ }^{1}$ Dept. of Atmospheric Science, Colorado State University, Fort Collins, CO, USA \\ ${ }^{2}$ University of Leeds, Leeds, UK \\ ${ }^{3}$ The University of Manchester, Manchester, UK \\ ${ }^{4}$ Max Planck Institute for Chemistry, Mainz, Germany \\ ${ }^{5}$ Pacific Marine Environmental Laboratory, NOAA, Seattle, WA, USA \\ ${ }^{6}$ Scripps Institution of Oceanography, University of California at San Diego, La Jolla, CA, USA \\ ${ }^{7}$ NASA/Goddard Space Flight Center, Greenbelt, MD, USA \\ ${ }^{8}$ School of Physics and Centre for Climate and Air Pollution Studies, National University of Ireland Galway, Galway, Ireland \\ ${ }^{9}$ Bigelow Laboratory for Ocean Sciences, West Boothbay Harbor, ME, USA \\ *now at: Harvard University, Cambridge, MA, USA
}

Received: 5 March 2011 - Published in Atmos. Chem. Phys. Discuss.: 8 April 2011

Revised: 16 July 2011 - Accepted: 12 August 2011 - Published: 1 September 2011

\begin{abstract}
Aerosol loading in the marine environment is investigated using aerosol composition measurements from several research ship campaigns (ICEALOT, MAP, RHaMBLe, VOCALS and OOMPH), observations of total AOD column from satellite (MODIS) and ship-based instruments (Maritime Aerosol Network, MAN), and a global chemical transport model (GEOS-Chem). This work represents the most comprehensive evaluation of oceanic OM emission inventories to date, by employing aerosol composition measurements obtained from campaigns with wide spatial and temporal coverage. The model underestimates AOD over the remote ocean on average by $0.02(21 \%)$, compared to satellite observations, but provides an unbiased simulation of ground-based Maritime Aerosol Network (MAN) observations. Comparison with cruise data demonstrates that the GEOS-Chem simulation of marine sulfate, with the mean observed values ranging between $0.22 \mu \mathrm{g} \mathrm{m}^{-3}$ and $1.34 \mu \mathrm{g} \mathrm{m}^{-3}$, is generally unbiased, however surface organic matter $(\mathrm{OM})$ concentrations, with the mean observed concentrations between $0.07 \mu \mathrm{g} \mathrm{m}^{-3}$ and $0.77 \mu \mathrm{g} \mathrm{m}^{-3}$, are underestimated by a factor of 2-5 for the standard model run. Addition of a sub-micron marine $\mathrm{OM}$ source of approximately $9{\mathrm{TgC} \mathrm{yr}^{-1}}^{-1}$ brings the model into agreement with the ship-based measurements, however this additional OM source does not ex-
\end{abstract}

Correspondence to: $\mathrm{K}$. Lapina

(klapina@atmos.colostate.edu) plain the model underestimate of marine AOD. The model underestimate of marine AOD is therefore likely the result of a combination of satellite retrieval bias and a missing marine aerosol source (which exhibits a different spatial pattern than existing aerosol in the model).

\section{Introduction}

The marine environment is generally associated with limited anthropogenic influence and clean conditions, however the oceans are a major source of natural aerosols to the atmosphere, including sea salt and sulfate. Knowledge of the aerosol natural background in the marine atmosphere is important for our ability to estimate the indirect climate forcing resulting from anthropogenic emissions. Measurement of substantial amounts of organic material in marine boundary layer (MBL) aerosol samples (Novakov et al., 1997; Cavalli et al., 2004; Facchini et al., 2008a), including plumes exceeding typical continental concentrations (Ovadnevaite et al., 2011), has sparked efforts to estimate marine emissions of organic aerosol and link these emissions to bioproductivity (e.g., O'Dowd et al., 2004; Gantt et al., 2009; Arnold et al., 2009). Here we utilize multi-campaign observations to investigate aerosol loading in the marine environment and whether ambient measurements support previously estimated marine OM emissions. 
The organic material in marine particles can originate from the mobilization of organic surfactants through sea spray (primary) as well as from the oxidation of biogenic VOCs emitted from the ocean (secondary). Estimates of oceanic isoprene sources are too small to lead to substantial OM production (Palmer and Shaw, 2005; Arnold et al., 2009; Gantt et al., 2009; Luo and Yu, 2010), however oceanic emissions of monoterpenes and other VOCs are not well constrained (Facchini et al., 2008b; Yassaa et al., 2008; Sinreich et al., 2010; Luo and Yu, 2010). Sea spray aerosol formation has been shown to depend on a number of environmental parameters, such as wind speed, atmospheric thermal stability, water temperature and salinity (Lewis and Schwartz, 2004; Monahan and O'Muircheartaigh, 1986; Martensson et al., 2003), but a mechanistic description of this process remains incomplete. The contribution of OM to aerosol loading over the ocean follows a seasonal pattern which has been linked to periods of low and high biological activity. Chlorophyll$a$ concentrations derived from satellites were found to be correlated with the observed OM concentrations and have served as a proxy for bioproductivity in many of these studies (O'Dowd et al., 2004; Yoon et al., 2007; Spracklen et al., 2008).

Recent estimates of OM from marine sources range between 2.3 to $75 \mathrm{TgC} \mathrm{yr}^{-1}$ (Spracklen et al., 2008; Roelofs, 2008; Langmann et al., 2008; Gantt et al., 2009; Ito and Kawamiya, 2010; Myriokefalitakis et al., 2010; Long et al., 2011; Vignati et al., 2010). This wide range reflects challenges and large uncertainties associated with quantifying these emissions, as well as differences in treatment (including both sub-micron and super-micron size ranges or primary and secondary sources). In this work we apply two approaches for modeling the marine sub-micron OM source and compare those with aerosol composition measurements from several ship-based campaigns.

\section{Model and measurements description}

\subsection{GEOS-Chem}

We use version v8-03-01 of the GEOS-Chem (http:// geos-chem.org/) global chemical transport model with $2^{\circ} \times$ $2.5^{\circ}$ horizontal resolution and 47 vertical levels, driven by GEOS-5 assimilated meteorology from the NASA Global Modeling Assimilation Office (GMAO). We conduct a series of coupled oxidant-aerosol simulations which include the sulfate/nitrate/ammonium thermodynamic scheme described in Park et al. (2004), dust (Fairlie et al., 2007), sea salt (Jaeglé et al., 2011), carbonaceous aerosols (Park et al., 2003) and continental secondary organic aerosol, as described by Liao et al. (2007). All aerosols are treated as externally mixed. All aerosols are sub-micron in size with the exception of sea salt and dust which are simulated in two and four size bins, respectively.
Sea salt in the model is emitted in two size bins as a function of wind speed following the formulation of Gong (2003) and is updated to include a 3rd order polynomial dependence on sea surface temperature (SST), based on fitting coarse mode sea salt concentrations measured during open-ocean cruises (Jaeglé et al., 2011). Jaeglé et al. (2011) showed that this updated sea salt source function reduces model bias for the cruises and ground-based stations, and improves agreement with MODIS and AERONET AOD (Fig. 9 in Jaeglé et al. (2011)). While sea salt emissions are very sensitive to the type of emissions parameterizations used (Pierce and Adams, 2006), a recent evaluation of different sea salt source parameterizations in the GISS global model shows that performance improves when this SST dependence is included (Kostas Tsigaridis, personal communication, 2011). Following this scheme, global sea salt emissions in 2007 total $55 \mathrm{Tg}$ in the accumulation mode and $3416 \mathrm{Tg}$ in the coarse mode.

Marine sulfate is produced from the oxidation of dimethyl sulfide (DMS) by $\mathrm{OH}$ and $\mathrm{NO}_{3}$ radical to form $\mathrm{SO}_{2}$ and methane sulfonic acid (MSA) (Park et al., 2004). Continental emissions of aerosols and aerosol precursors include biomass burning specified following the monthly GFED2 inventory (Van der Werf et al., 2006), biofuel (Yevich and Logan, 2003) and fossil fuel following the global EDGAR v3.2 inventory (Olivier and Berdowski, 2001) for all species other than carbonaceous aerosols which follow Bond et al. (2007). An OM:OC ratio of 2.1 is applied to simulated OC concentrations to account for the noncarbon component of organic mass (Turpin and Lim, 2001). Conversion of hydrophobic to hydrophilic carbonaceous aerosols takes place with an efolding time of 1.2 days based on Cooke et al. (1999). Continental biogenic VOC emissions are predicted interactively in GEOS-Chem using MEGAN2 (Guenther et al., 2006).

The AOD at $550 \mathrm{~nm}$ is calculated from the mass concentration, extinction efficiency, effective radius, and particle mass density as a function of local relative humidity according to the formulation of Tegen and Lacis (1996), as described by Martin et al. (2003). The AOD is sensitive to the assumed size distribution of the aerosols (see Sect. 3 for specific discussion regarding OM size.) Optical properties have been recently updated based on the observed size distributions of organics, BC and sulfate following Drury et al. (2010) and for sea salt by Jaeglé et al. (2011).

\subsection{Modeling marine OM aerosol}

We use two approaches to estimate the global marine source of sub-micron organic aerosol and evaluate these against the observations. Spracklen et al. (2008) scaled marine OM emissions to remotely-sensed chlorophyll- $a$ concentrations, [Chl- $a$ ]. An emission factor, $(A)$, was derived to obtain the best match between the modeled and observed OM concentrations at three island sites, i.e., ( $\left.\mathrm{OM}_{\mathrm{emis}}=A \times[\mathrm{Chl}-a]\right)$. The resulting emission fluxes were 
modeled as sub-micron OM, although the magnitude of these emissions was constrained based on the observations that were not strictly $\mathrm{PM}_{1}$. Based on the published observations in the North East Atlantic, Spracklen et al. (2008) further suggested that $70 \%$ of their total OM emissions is submicron. In this work we assume that all $\mathrm{OM}$ is in submicron mode, as simulated. The impact of meteorological parameters on emissions, such as wind speed, was not considered explicitly in this study due to the insufficient temporal resolution of the data used (weekly measurements). We use the same emission factor, $(A)$, for all three years studied in this work. Global concentrations of chlorophyll- $a$ were specified from SeaWIFS for 2006 and 2007 (Level-3 binned global fields, available at http://oceancolor.gsfc.nasa. gov/SeaWiFS/). Because of the missing periods in SeaWIFS fields for 2008 we use monthly-mean mapped MODIS Level 3 chlorophyll- $a$ data obtained from the NASA Goddard Ocean Color group (http://oceancolor.gsfc.nasa.gov/) for this year. Chlorophyll- $a$ concentrations measured by these two instruments are consistent (Zhang et al., 2006; Fiorani et al., 2008). These data were re-gridded to the model resolution to drive marine OM emissions. Following Spracklen et al. (2008) we emit marine OM with the same sub-micron size distribution as existing continental OM. Global OM emissions total $8.9 \mathrm{TgC}^{-1}$ in 2007 with this scheme (7.7 $\mathrm{TgC} \mathrm{yr}^{-1}$ in 2006 and 9.0 $\mathrm{TgC} \mathrm{yr}^{-1}$ in 2008).

O'Dowd et al. (2008) developed an alternate method of specifying sub-micron marine OM emissions for inclusion in a regional model, which Langmann et al. (2008) and Vignati et al. (2010) applied globally. Their combined organicinorganic sub-micron sea spray source function is based on wind speed and surface ocean chlorophyll- $a$ concentration. In this model chlorophyll- $a$ determines the organic contribution to the aerosol sub-micron sea spray flux. Therefore, seasalt dominates sea spray mass in the winter while the organic fraction increases during biologically-active periods. To derive marine organic emissions following this approach, we combined this organic-inorganic sea-spray separation with the online GEOS-Chem source function for accumulation mode sea salt, discussed in Sect. 2.1. As a result, marine OM emissions depend on chlorophyll- $a$, wind speed and SST. No change is applied to the sea salt emissions, while total sea spray flux is increased due to addition of marine organics. The fraction of organic mass, $(\% \mathrm{OM})$, is calculated following Langmann et al. (2008) (with typographical correction noted in Vignati et al. (2010)):

$\%_{\mathrm{OM}}=49.129 \times[\mathrm{Chl}-a]+10$

where $\%$ OM is restricted within the range between $10 \%-$ $90 \%$ and [Chl- $a$ ] is in units of $\mu \mathrm{g} \mathrm{m}^{-3}$. Vignati et al. (2010) used the TM5 model coupled to a microphysical aerosol dynamics model, with the sea spray emissions in coarse and accumulation modes. Their accumulation mode sea spray was partitioned into OM and sea salt, with the OM fraction computed using a slightly modified formula from the one used here, based on a revised analysis. They estimate that the difference between use of their relationship and the one by Langmann et al. (2008) is small (a maximum of 4\%). In their work they also increased the modal diameter to account for the greater OM contribution during the periods of high biological activity. The fact that their partitioning function was applied to the aerosol with varying modal diameter implies a larger increase in OM mass during the periods of high biological activity, compared to the approach here. However, this difference will be partly compensated by the underlying SST dependence in sea salt function by Jaeglé et al. (2011). The shipboard data used here cannot provide any insight on the strength of the seasonality of emitted OM to better constrain the temporal behavior of these emissions in the model.

Global chlorophyll- $a$ concentrations are specified following the same satellite-derived MODIS and SeaWIFS products used when implementing the Spracklen et al. (2008) emissions. Marine OM is emitted with the same size distribution as assumed with the Spracklen et al. (2008) scheme for ease of comparison and is constant. The geometric radius of this log-normal size distribution is $23 \%$ smaller than the one for the sea salt accumulation mode. These size differences have little impact on simulated deposition and burden. The impact of OM size on AOD is discussed in Sect. 3.

Although the two approaches vary through the underlying assumptions and their implementation, the resulting marine flux of $\mathrm{OM}\left(8.2 \mathrm{TgC} \mathrm{yr}^{-1}\right.$ in 2007) estimated using the Langmann et al. (2008) approach, agrees well with the emissions obtained by Spracklen et al. (2008). Differences between our estimate using Langmann et al. (2008) and estimates of Langmann et al. (2008) $\left(2.8 \mathrm{TgC} \mathrm{yr}^{-1}\right)$ and Vignati et al. (2010) $\left(5.8 \mathrm{TgC} \mathrm{yr}^{-1}\right)$ are likely the result of different sea salt parameterizations (see Sect. 2.1). For example, Vignati et al. (2010) report global emissions of fine sea salt to be $24 \mathrm{Tg} \mathrm{yr}^{-1}$, which is less than half of what was obtained in the current work $\left(55 \mathrm{Tg} \mathrm{yr}^{-1}\right)$, and can partially explain a larger OM source presented here. Sea salt emissions were not reported in Langmann et al. (2008). Additional factors, such as true interannual variability in sea salt emissions, can also contribute to this difference. Vignati et al. (2010) also include a size dependence of marine $\mathrm{OM}$ as a function of chlorophyll- $a$, which we do not consider here. The differences in spatial distribution of emissions (Fig. 1), such as lower OM in some of the chlorophyll- $a$ rich coastal regions and higher OM in the high latitudes of the Southern Hemisphere in the Langmann et al. (2008) scheme, reflects the fact that this approach includes dependence on wind speed and SST, while the Spracklen et al. (2008) is based on chlorophyll- $a$ concentrations only. In both cases, emitted marine $\mathrm{OM}$ is treated as hydrophobic, consistent with Spracklen et al. (2008). This is based on indications that primary marine $\mathrm{OM}$, which is a major contributor to the total marine OM (Gantt et al., 2009), is mainly water-insoluble (Facchini et al., 2008a). However, given the rapid conversion of hydrophobic to hydrophilic OM, $>60 \%$ of OM burden in 
OM [Spracklen et al. 2008]

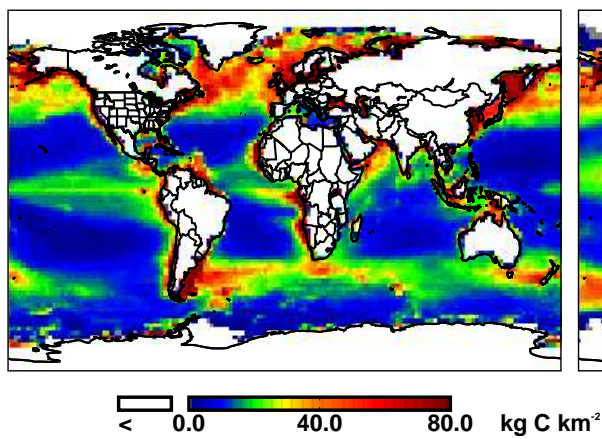

OM [Langmann et al. 2008]
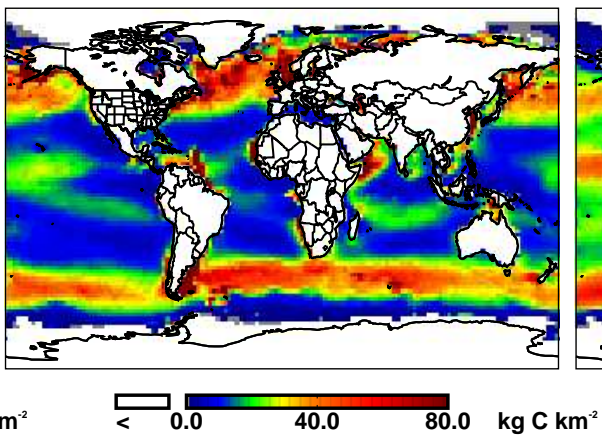

Sea salt [Jaegle et al. 2011]
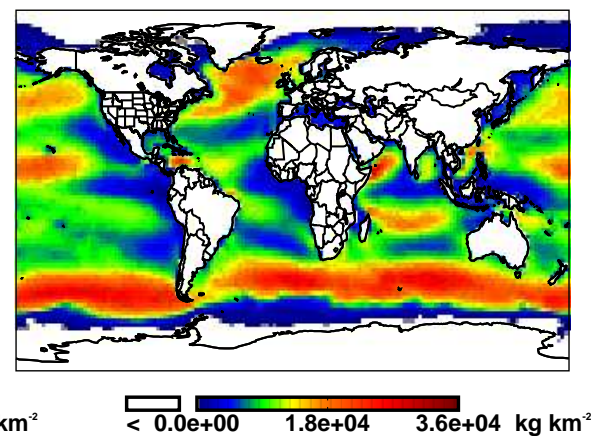

Fig. 1. Global distribution of total annual emissions for 2007 of marine OM by Spracklen et al. (2008) (GC ) (left), Langmann et al. (2008) $\left(\mathrm{GC}_{\mathrm{L}}\right)$ (center) and sea salt by Jaeglé et al. (2011) (right). As discussed in the text, both OM parameterizations are functions of [Chl- $a$ ]. The Langmann et al. (2008) scheme additionally includes dependence on wind speed and SST, as implemented here.

the model is made up of hydrophilic OM. Spracklen et al. (2008) estimate that increasing the timescale of conversion by a factor of 2 would decrease the OM source by $12 \%$ to simulate equivalent concentrations. Emitting this aerosol as hydrophilic would imply a relatively small increase in total emissions required to match observed aerosol concentrations in order to compensate for the increase in removal rate (Spracklen et al., 2008). We do not include marine SOA explicitly in the model, however comparisons between the model and observations (to follow) implicitly constrain total marine $\mathrm{OM}$ and may include secondary particles.

\subsection{Measurements of aerosol composition}

We use ship-based measurements of aerosol composition in the MBL obtained during research campaigns that took place in 2006 to 2008. All measurements were performed using several models of the Aerodyne Aerosol Mass Spectrometers (AMS) (Jayne et al., 2000; DeCarlo et al., 2006; Canagaratna et al., 2007). Ship tracks and dates of the campaigns are shown in Fig. 2. These field experiments include the Marine Aerosol Production (MAP) (http://macehead. nuigalway.ie/map/), Organics over the Ocean Modifying Particles in both hemispheres (OOMPH) (Zorn et al., 2008), Reactive Halogens in the Marine Boundary Layer (RHaMBLe) (Lee et al., 2010), International Chemistry Experiment in the Arctic LOwer Troposphere (ICEALOT) (Russell et al., 2010; Frossard et al., 2011) and the VAMOS OceanCloud-Atmosphere-Land Study (VOCALS) (Hawkins et al., 2010). The described campaigns used different types of AMS, including a High Resolution AMS (HR-AMS) (DeCarlo et al., 2006) during MAP, OOMPH and RHaMBLe, and Quadrupole AMS (Q-AMS) during ICEALOT and VOCALS (Jayne et al., 2000; Allan et al., 2003; Frossard et al., 2011).

All measurements were performed with AMS instruments with a standard size cut, which provide real-time observations of non-refractory species in submicrometer particles,

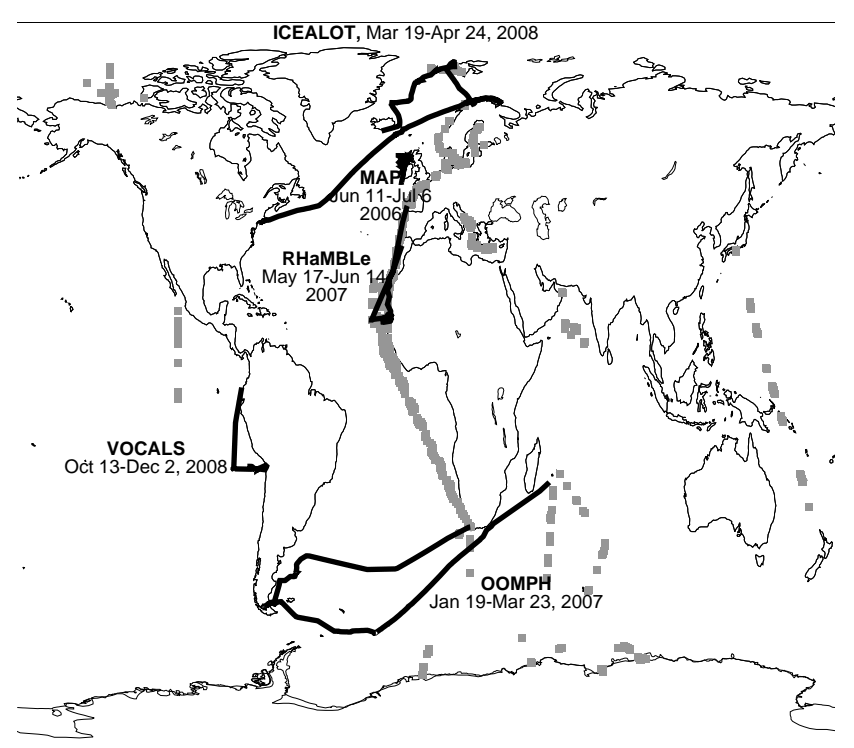

Fig. 2. Tracks of the research ship campaigns used in this work (black lines) and Maritime Aerosol Network sunphotometer sampling locations (gray squares).

including sulfate, organic matter, nitrate and ammonium. As AMS observations are limited to sub-micron sizes (estimated to be approximately $800 \mathrm{~nm}$ ) (DeCarlo et al., 2004) and we simulate only those fine marine OM aerosols in GEOSChem, in the discussion that follows we exclusively consider fine aerosols. Analysis of $\mathrm{PM}_{1}$ and $\mathrm{PM}_{10}$ filter measurements obtained during the ICEALOT campaign showed that $\mathrm{PM}_{1}$ data agreed well with AMS data, and suggested no significant contribution of coarse OM. A discussion of the potential role of coarse OM particles is included in Sect. 3. Hawkins et al. (2010) compared Fourier transform infrared (FTIR) measurements with AMS data for VOCALS and found that the AMS OM was more than a factor of two lower, on average, than FTIR OM. They suggested reduced collection 
efficiency as one of the possible reasons for this discrepancy (Hawkins et al., 2010). For the ICEALOT campaign, however, we find that AMS OM agrees well with the reported FTIR measurements (Russell et al., 2010). These results suggest that AMS may represent a lower limit of fine OM in certain environments. AMS measurements were reported every few minutes, which were further averaged to obtain hourly averages used in this work. To ensure that the AMS data were representative of air in the remote marine regions, periods when air masses were affected by fresh continental pollution were excluded prior to the analysis. These pollution episodes were identified on the basis of simultaneously occurring enhanced concentrations of sulfate and nitrate in the aerosol samples. While sulfate concentrations contribute a major fraction to the total aerosol mass and can potentially serve as a tracer for continental pollution alone, presence of high nitrate helped to rule out the DMS marine source of sulfate. Concentrations were considered high when the hourly averages exceeded the 70th percentiles of the measurements for the considered campaign (cutoff concentrations are listed in Table 1). While other anthropogenic tracers were available in some datasets (e.g., radon and black carbon) these were not available across all campaigns. We select these criteria so that they can be consistently applied for all datasets. We followed this with a visual inspection of the time series to ensure that all obvious plumes of continental origin are removed. We found that the results discussed here are not sensitive to the cutoffs used. The applied screening removed between 11 and $20 \%$ of the measurements for each campaign, which resulted in reduction by $12-50 \%$ in OM and by $8-44 \%$ in sulfate concentrations. The OM values in clean marine airmasses obtained in this work compared well with the numbers reported by Hawkins et al. (2010) for VOCALS using FTIR, but were higher than the values in the ICEALOT campaign using the same technique (Russell et al., 2010). This disagreement is likely due to the different approach used to derive clean marine OM values for ICEALOT (i.e., Positive Matrix Factorization). Our mean $\mathrm{OM}$ value $\left(0.77 \mu \mathrm{g} \mathrm{m}^{-3}\right.$, see Table 1) is higher than the number obtained by Allan et al. (2009) during RHaBMLe for their "clean" 40-h period $\left(0.29 \mathrm{\mu g} \mathrm{m}^{-3}\right)$, identified based on the back trajectories analysis. Their criteria were more conservative and they excluded time periods with measurements exhibiting high variability in composition and air mass history. For the OOMPH campaign, the resulting mean $\mathrm{OM}$ of $0.05 \mathrm{\mu g} \mathrm{m}^{-3}$ was in reasonable agreement with the values reported by Zorn et al. (2008) for the periods without strong continental influence (e. g., the "African outflow" period identified in their work was successfully filtered out by our screening criteria).

\subsection{Measurements of Aerosol Optical Depth (AOD)}

In this work we use observations from the MODIS instrument aboard the Terra satellite with 1030 local overpass time. The daily gridded AOD (at $550 \mathrm{~nm}$ ) v5 confidence-weighted mean (QA_Mean) ocean product with $1^{\circ} \times 1^{\circ}$ resolution was regridded to $2^{\circ} \times 2.5^{\circ}$ for comparison with GEOS-Chem AOD. Grid squares with cloud fraction exceeding $50 \%$ were removed in order to minimize cloud contamination following Zhang et al. (2005) and Remer et al. (2008). MODIS annual mean AOD was calculated by weighting daily (Level 3) data by the number of Level 2 measurements in each grid box following Levy et al. (2009). This is consistent with the filtering applied by Jaeglé et al. (2011) when investigating the contribution of sea salt to AOD. However, Jaeglé et al. (2011) used Aqua AOD v5 aerosol product, which was found to be 0.015 lower over the global ocean than Terra AOD used in this work (Remer et al., 2008). To compare GEOS-Chem AOD with MODIS data, the model was sampled at the time and location of MODIS overpass.

The Maritime Aerosol Network (MAN) is a component of the Aerosol Robotic Network (AERONET), and provides measurements taken with the Microtops II sunphotometers from various ships of opportunity (Smirnov et al., 2009). The direct Sun measurements are acquired in five spectral channels within the spectral range $340-1020 \mathrm{~nm}$. AOD at $550 \mathrm{~nm}$ is calculated by linearly interpolating AOD at $440 \mathrm{~nm}$ and $675 \mathrm{~nm}$ in the log domain. We use Level 2 data for 2007 (Fig. 2). Further description of the sunphotometer can be found elsewhere (Morys et al., 2001; Knobelspiesse et al., 2004). To include measurements representative of the clean marine environment, we excluded data with AOD exceeding 0.4 . The excluded data made up $8 \%$ of the total measurements and are primarily located in regions exposed to African dust outflow.

\section{Results and discussion}

Maps of seasonally-averaged AOD reveal that GEOS-Chem captures the spatial patterns in MODIS data $(r=0.63$ for the region between $60^{\circ} \mathrm{S}$ and $60^{\circ} \mathrm{N}$ ), but underestimates AOD over the large portions of ocean regions, with a few exceptions, by $23 \%$, on average, based on the annual mean, compared to MODIS (Fig. 3). Biases in continental outflow could contribute to this. Note that marine $\mathrm{OM}$ is not included in this standard GEOS-Chem simulation. Over the remote ocean regions, defined here as the regions with MODIS AOD $<0.15$, with the cutoff based on the multiannual global mean AOD value of 0.14 over oceans for Terra MODIS (Remer et al., 2008) (clean marine conditions can be characterized even with lower AOD (Smirnov et al., 2002)), this is equivalent to a mean underestimate of 0.02 in AOD (i.e., $21 \%$ ). We find that MODIS AOD is sensitive to the filtering assumptions made. For example, allowing for grid cells with cloud fraction of up to $80 \%$ in the daily gridded Level 3 product, compared to the maximum cloud fraction of $50 \%$, leads to an increase in annual mean ocean AOD by 0.01 , thus to a mean underestimate of 0.03. Zhang and Reid (2006) developed a high-quality MODIS over-water AOD product by reducing 
MODIS AOD

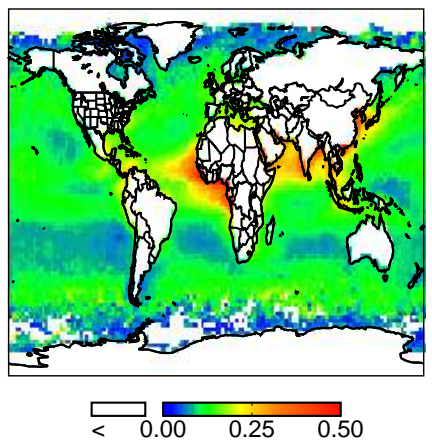

GEOS-Chem AOD

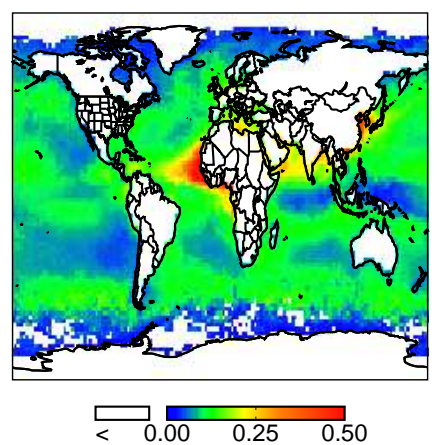

$\%$ difference

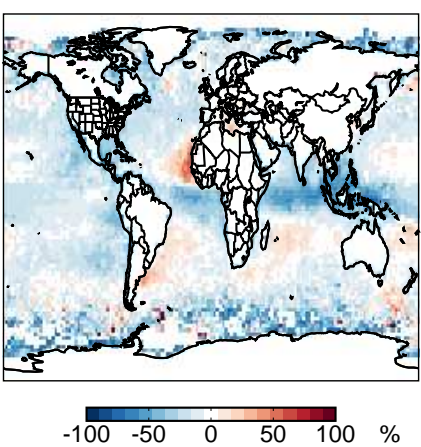

Sea salt GEOS-Chem AOD

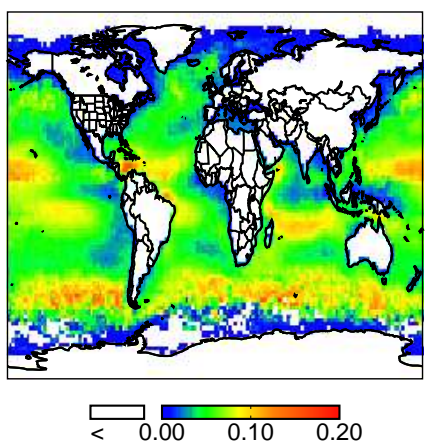

Fig. 3. Annual average aerosol optical depth (AOD) at $550 \mathrm{~nm}$ in 2007 for MODIS, GEOS-Chem, \% difference (GEOS-Chem-MODIS) and sea salt component of GEOS-Chem. Model was sampled at the time and location of MODIS overpass.

Table 1. Summary of modeled and measured aerosol concentrations by campaign. All units $\left(\mu \mathrm{g} \mathrm{m}^{-3}\right)^{\mathrm{a}}$.

\begin{tabular}{|c|c|c|c|c|c|c|c|c|}
\hline \multirow[t]{2}{*}{ Campaign } & \multicolumn{2}{|c|}{ Cutoffs } & \multicolumn{4}{|c|}{ OM, Mean (SD) } & \multicolumn{2}{|c|}{ Sulfate, Mean (SD) } \\
\hline & Nitrate & Sulfate & Obs & GC & $\mathrm{GC}_{\mathrm{S}}$ & $\mathrm{GC}_{\mathrm{L}}$ & Obs & GC \\
\hline ICEALOT & 0.03 & 1.58 & $0.48(0.27)$ & $0.19(0.44)$ & $0.57(0.61)$ & $0.49(0.67)$ & $1.07(0.64)$ & $0.54(0.22)$ \\
\hline MAP & 0.03 & 0.53 & $0.25(0.24)$ & $0.08(0.10)$ & $1.15(0.55)$ & $0.59(0.46)$ & $0.40(0.17)$ & $0.98(0.48)$ \\
\hline RHaMBLe & 0.08 & 2.13 & $0.77(0.84)$ & $0.09(0.07)$ & $2.63(3.58)$ & $4.04(5.19)$ & $1.34(1.08)$ & $1.07(0.54)$ \\
\hline VOCALS & 0.02 & 1.01 & $0.17(0.12)$ & $0.09(0.05)$ & $0.37(0.28)$ & $0.28(0.17)$ & $0.69(0.44)$ & $0.74(0.82)$ \\
\hline OOMPH & 0.01 & 0.34 & $0.05(0.07)$ & $0.01(0.03)$ & $0.64(0.91)$ & $0.68(1.08)$ & $0.22(0.14)$ & $0.32(0.19)$ \\
\hline
\end{tabular}

${ }^{a}$ Reported are the cutoffs used to screen pollution events for each campaign, mean and standard deviation (SD) for the observed concentrations (Obs), for the model simulation without marine OM (GC), with marine OM from Spracklen et al. (2008) $\left(\mathrm{GC}_{\mathrm{S}}\right)$ and with marine OM from Langmann et al. (2008) (GC $\mathrm{L}$ ).

the systematic biases present in Level 2 MODIS data through empirical corrections and quality assurance procedures. Using this product reduces AOD differences between the model and MODIS, resulting in the mean AOD underestimate of 0.01 over the remote regions. However, some low model bias remains in all these cases. This is consistent with the works of Smirnov et al. (2011) and Jaeglé et al. (2011), with the latter suggesting that this bias can be largely attributed to fine-mode AOD.

To examine the nature of this discrepancy we compare the model with the in-situ sunphotometer measurements. Figure 4a presents a scatterplot of GEOS-Chem total AOD versus sunphotometer data with regression statistics calculated using the geometric mean (reduced major axis) two-sided regression technique (Ayers, 2001; Draper and Smith, 1998). Here GEOS-Chem was sampled at the time and location of the sunphotometer observations. The model generally captures the variability in the sunphotometer data $(r=0.77)$, and is unbiased (based on slope $=1.00$ when considering only points with AOD < 0.4). MODIS AOD is also highly correlated with the sunphotometer values, but is biased slightly low (slope =0.90) (Fig. 4b). Although the model does not exhibit low bias against the MAN data, the number of MAN observations involved is limited and, hence, we cannot reject the possibility of low AOD in the model. Alternatively, the observed difference between the model and satellite data could be due to the uncertainty in satellite AOD retrieval, which is reported as $\pm 0.03+0.05$ AOD for individual retrievals over oceans for Terra (Remer et al., 2008). Given that the disagreement between the model and satellite data is based on a large number of MODIS observations, averaged over large temporal and spatial scales, this difference seems beyond the expected uncertainties. An alternative explanation may be an underestimate in simulated aerosol sources. Following a recent update in the sea salt source function, simulated coarse-mode AOD agrees well with the observations (Jaeglé et al., 2011). Coarse mode sea salt contributes on average $70 \%$ of the marine AOD in clean regions. While less than $2 \%$ of sea salt mass is emitted in the fine mode, it contributes on average $20 \%$ of the total sea salt AOD due to the efficiency of small particle extinction in the mid-visible. Hence, the AOD bias could be due to fine sea salt component. However, the spatial pattern in AOD difference (Fig. 3) is anticorrelated with sea salt AOD simulated in the model (Fig. 3, right panel), with $r=-0.40$, for the remote ocean regions. Analysis of AOD maps by season also suggests that the temporal variability in sea salt AOD in the low-AOD regions cannot account for the AOD bias (e.g., the largest underestimate in AOD in the North Pacific ocean is in the summer, when sea salt AOD is at its seasonal minimum). Based 

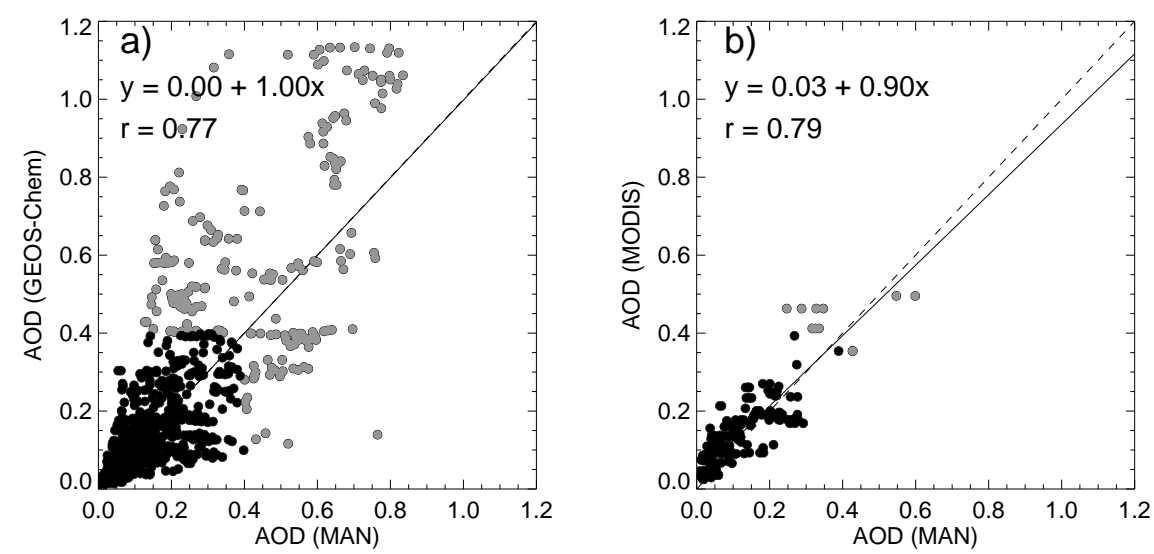

Fig. 4. Scatter plot of (a) modeled AOD and (b) MODIS AOD against sunphotometer measurements (MAN), sampled to coincide with MODIS overpass. Regression lines (solid black lines) are computed for datapoints with AOD $<0.4$ (black dots) by the reduced major axis method (Ayers, 2001; Draper and Smith, 1998). A 1:1 line is also shown (dashed line). Datapoints with AOD $>0.4$ are shown in gray.

on anticorrelation in spatial distribution and seasonal variability of the regions with low AOD, it seems unlikely that this low bias can be attributed to an underestimate of sea salt in the model. To test the model's performance for individual aerosol components, we compare ship-based AMS data to the model-predicted surface concentrations of sulfate, which is a major contributor to the total AOD globally. Measured mean sulfate concentrations range from $0.22 \mu \mathrm{g} \mathrm{m}^{-3}$ for OOMPH to $1.34 \mu \mathrm{g} \mathrm{m}^{-3}$ for the RHaMBLe (Table 1). The model agrees relatively well, on average, with the measurements (Fig. 5), in some cases overestimating measured sulfate suggesting that it is unlikely that low AOD is due to a model underestimate in sulfate. ICEALOT is the only campaign where GEOS-Chem is biased low, consistent with previous findings that models underestimate springtime Arctic sulfate concentrations (Shindell et al., 2008). (Sulfate is also somewhat underestimated during RHaMBLe, but this underestimate is within the variability of the observations.)

Organic matter is the second largest contributor to the nonrefractory aerosol mass during the campaigns examined here. These campaigns took place during the biologically productive seasons (i.e., mainly spring and summer). Mean OM concentrations range from $0.07 \mu \mathrm{g} \mathrm{m}^{-3}$ during OOMPH to $0.77 \mu \mathrm{g} \mathrm{m}^{-3}$ for RHaMBLe. Comparison of the standard GEOS-Chem simulation (with no marine OM) with measurements demonstrates a large underestimate in surface $\mathrm{OM}$ aerosol concentrations for all studied campaigns (see Fig. 5). To test whether the inclusion of marine organic source improves the agreement with observations, we implemented oceanic OM emissions following the approach of Spracklen et al. (2008). This simulation resulted in improved agreement for ICEALOT (Fig. 5), but led to overestimates in OM in other regions, especially those with high biological productivity, as indicated by high chlorophyll- $a$ concentrations (Fig. 6). For example, very high modeled OM concentrations during RHaMBLe in the upwelling region west of Maurita- nia were not supported by measurements (Fig. 6). Vignati et al. (2010) also observed sensitivity of modeled OM to high coastal chlorophyll- $a$ concentrations.

As discussed in Sect. 2.2, the approach of Spracklen et al. (2008) does not take into account the dependence of marine emissions on sea spray production, which is largely driven by meteorological parameters. We investigate whether better agreement is achieved when these parameters are taken into account, by performing another model simulation, with marine OM source parameterization following Langmann et al. (2008). The second simulation improves agreement with OM measured during VOCALS and MAP (Fig. 5), but OM concentrations in the high chlorophyll- $a$ regions remain too high for the RHaMBLe and OOMPH campaigns. Agreement for ICEALOT is somewhat poorer for this simulation as well. A recent study (Gantt et al., 2011) suggests that organic enrichment of the air-sea interface is inversely correlated to wind speed, with the highest enrichments expected during calm winds. Application of an OM:OC conversion factor of 1.4 reported for the marine OM by Facchini et al. (2008a), rather than 2.1, as used here, would slightly improve agreement for all campaigns with the exception of ICEALOT. We note that adding an explicit marine SOA source in the model would increase simulated OM and thus would further degrade this comparison. However, different spatial/temporal patterns from secondary sources could improve the variability in simulated OM.

Most studies that relate marine OM to bioproductivity use monthly satellite-based chlorophyll- $a$ data (e.g., Langmann et al., 2008; O'Dowd et al., 2008). These monthly-means cannot be expected to provide small-scale details, but rather to reasonably represent the regional average. In addition to their coarse temporal and spatial resolution, satellite data can also be associated with significant random and systematic uncertainties, with the combined error of $\sim 30 \%$ (Vignati et al., 2010). In-situ ship-measured chlorophyll- $a$ observations 

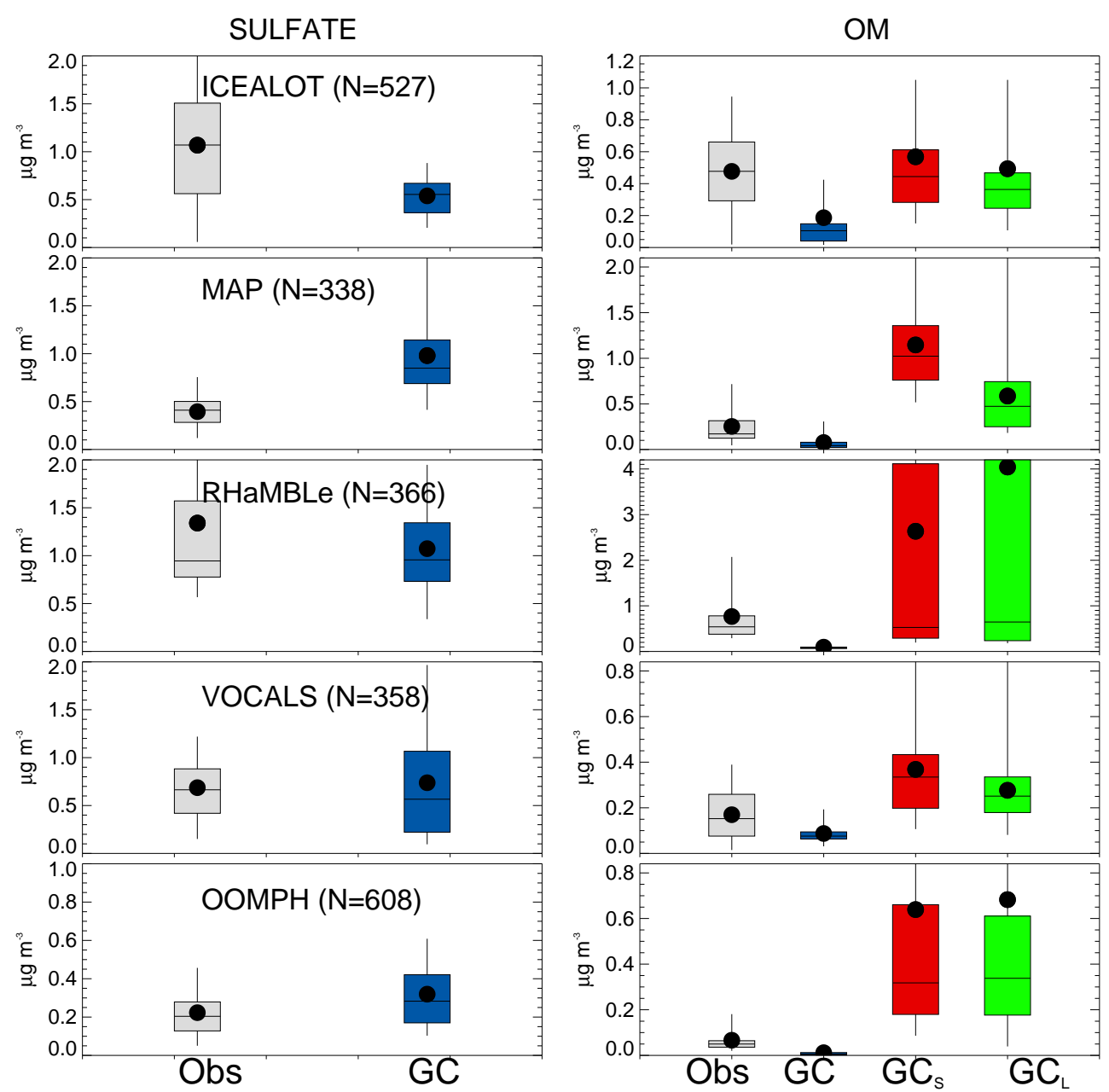

Fig. 5. Boxplots for measured and modeled surface sulfate (left) and OM (right) aerosol concentrations. Measurements are shown in gray.

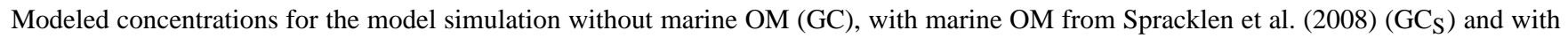
marine OM from Langmann et al. (2008) $\left(\mathrm{GC}_{\mathrm{L}}\right)$ are plotted in blue, red and green, respectively. Individual campaigns are shown on each row, with number of observations $(N)$ given in inset. Only values within the y-axis range are shown.

were available for two out of five campaigns studied here. We compared the monthly-mean satellite chlorophyll- $a$ data, sampled along the ship tracks, with the in-situ fluorometric measurements for the VOCALS and OOMPH campaigns. Satellite data reproduced the magnitude of the in-situ data for the OOMPH campaign, but were a factor of two low compared to the data collected during VOCALS. Ship-based chlorophyll- $a$ measurements exhibited high variability compared with the satellite products. This implies that monthlymean chlorophyll- $a$ satellite products may not be a good proxy for bioproductivity. It is therefore possible that the inability of satellite data to represent the chlorophyll- $a$ magnitude for some regions is one of the reasons for the poor performance of the model.

While several studies have found a positive correlation between marine organic aerosol and chlorophyll- $a$ concentrations e.g. (Yoon et al., 2007; Sciare et al., 2009), this does not hold in all regions (Russell et al., 2010). For example, while Russell et al. (2010) found a strong correlation between OM fraction and wind speed, there was no relationship with chlorophyll- $a$. We do not have wind speed observations for all campaigns to investigate this relationship. The assumed functional relationship between the OM fraction and $[\mathrm{Chl}-a]$ is another important source of uncertainty which can lead to substantial differences in the modeled OM (Long et al., 2011). We found a weak positive correlation between the AMS organics and fluorometer measurements for the VOCALS campaign $(r=0.35)$, but no relationship for OOMPH. Recent work demonstrated the importance of accounting for the air mass history when analyzing the variability in atmospheric tracers (Arnold et al., 2010). We found a marginal improvement in correlation between the organics and chlorophyll- $a$, when the latter was averaged over 2-day back-trajectories. 
GEOS-Chem OM, standard run
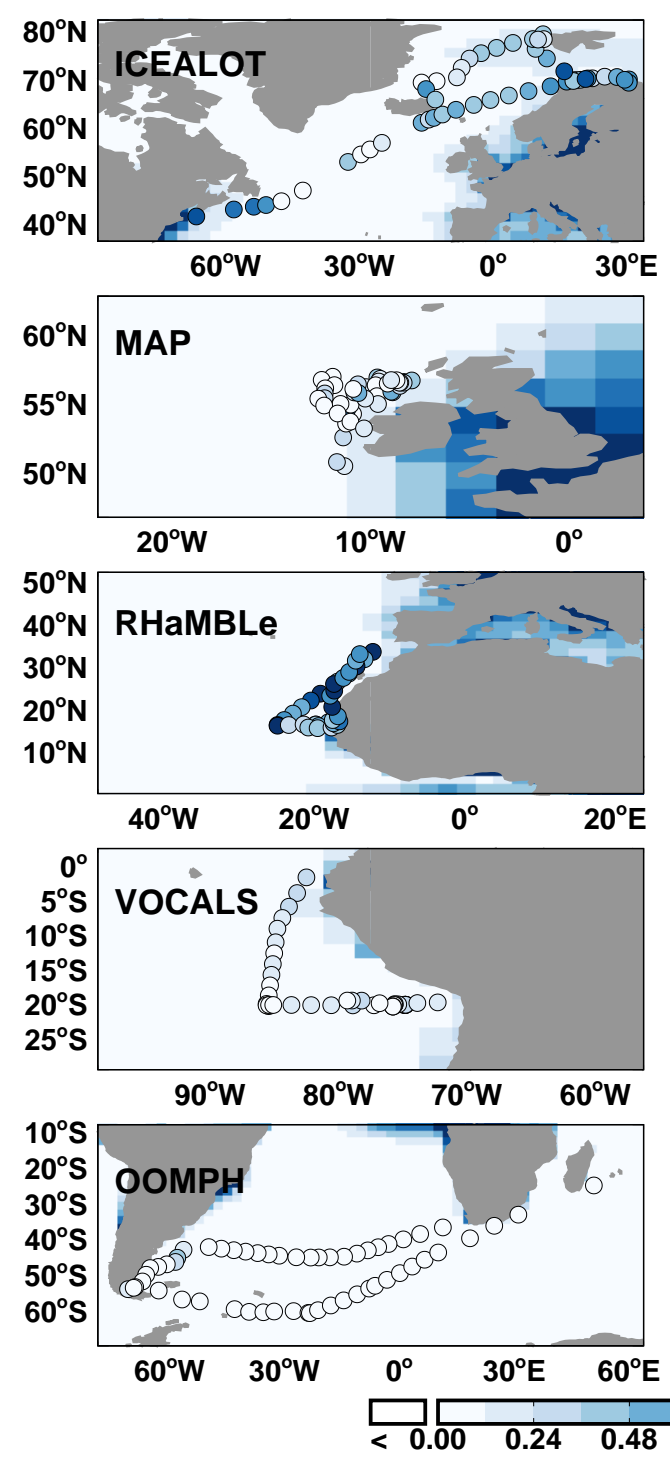

GEOS-Chem OM, with oceanic source
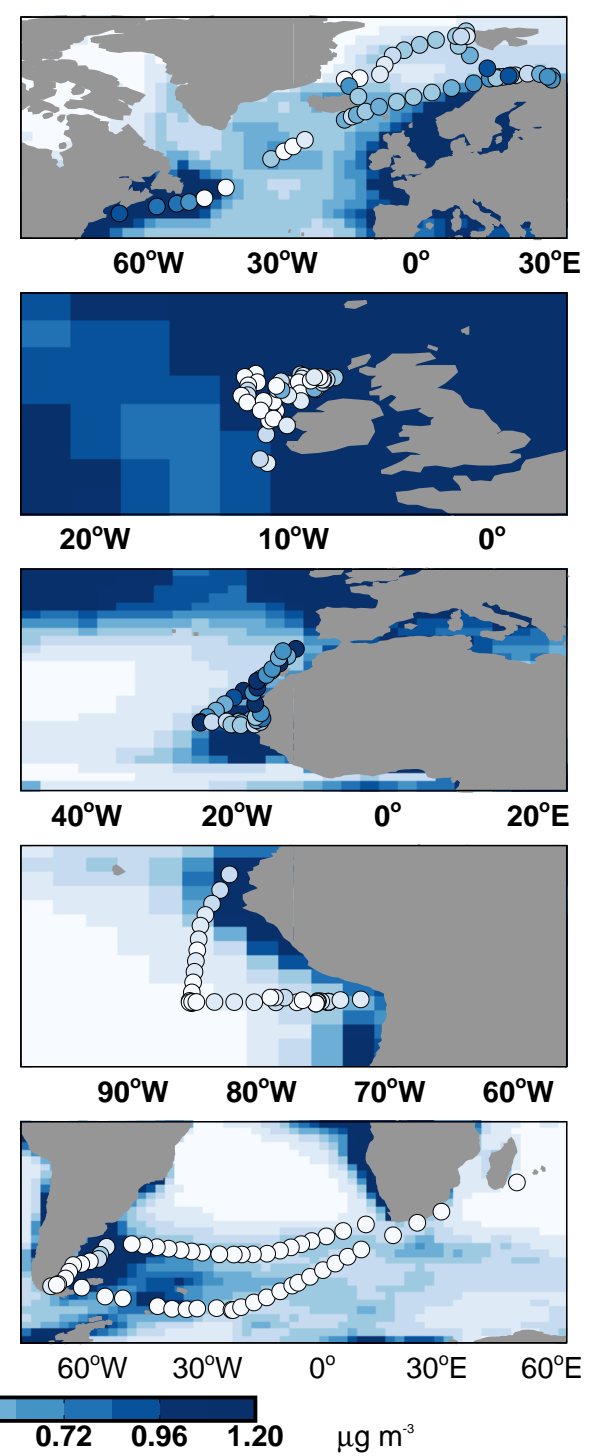

Fig. 6. Modeled surface OM concentration averaged over the period of each campaign without (left) and with (right) marine OM source by Spracklen et al. (2008) overlaid with OM observations. Color scale is saturated at the maximum values indicated in the legend.

The absence of a strong correlation between organic aerosol concentrations and chlorophyll- $a$ measurements can also be due to the fact that sea spray production is the dominant OM source. Thus, it is the organic fraction of sea spray aerosol that should be related to chlorophyll- $a$ exposure, rather than OM itself. Measurements of the sea salt component of sea spray (not detected by AMS) would be required to verify this relationship.

As the lifetime of sub-micron marine aerosol is on the order of several days, the presence/lack of correlation with the in-situ chlorophyll- $a$ data for different regions may be influenced by both the proximity and geographical location of the bioproductive areas as well as the phytoplankton type and conditions in the algal blooms. Alvain et al. (2005) has iden- tified the major dominant phytoplankton functional types from SeaWiFS measurements. The degree of correlation between atmospheric tracers and exposure to chlorophyll- $a$ has been shown to be dependent on these types (Arnold et al., 2010). Recent work by Fuentes et al. (2010) has further shown that the relationship between chlorophyll- $a$ and organic mass fraction in aerosols are expected to be very complex, as seawater OM production by marine biota depends on conditions in the algal blooms, including nutrient availability, temperature and lifespan of algal cells.

Despite an improved agreement with measured OM concentrations, the effect of adding marine OM in the model resulted in a marginal increase in AOD (by less than 0.003, on average), which is almost an order of magnitude lower than 
what would be required to achieve closure with the MODIS AOD. The spatial pattern in AOD difference between the model and MODIS shows a weak correlation with AOD due to organic material $(r=0.26$ for the remote ocean regions between $60^{\circ} \mathrm{S}$ and $60^{\circ} \mathrm{N}$ ). Calculating AOD from aerosol mass requires knowledge of aerosol extinction properties, which depend on the aerosol size distribution and optical properties. Heald et al. (2010) showed that mass extinction efficiency of organic aerosol is most sensitive to the size of aerosol, described by the geometric mean radius of the aerosol lognormal distribution. It is possible that the size of the OM employed in the model and validated for continental conditions (Drury et al., 2010), does not accurately reflect the size of marine aerosol. We calculate that increasing the geometric mean radius up to a factor of two leads to an increase in AOD, with the maximum increase of a factor of 1.4 (at relative humidity $=50 \%$ ), while further increase in size leads to a decrease in AOD. When the geometric mean radius is increased by a factor of 4 , AOD is $90 \%$ of the current value in the model, implying that even more organic mass is needed to produce the same AOD. The magnitude of this change is insufficient to explain the AOD underestimate in GEOS-Chem. The total AOD calculation in the model also largely depends on extinction properties of aerosol species other than OM. While Jaeglé et al. (2011) have recently evaluated and updated the sea salt optical properties and size distribution in GEOS-Chem, it is possible that an underestimate in the size of marine sulfate could contribute to a low model bias compared to MODIS. We note that a doubling of the mass extinction efficiency of sulfate would be required to eliminate the mean model bias. However, while increasing the AOD from existing aerosols in the model, either sulfate or sea salt, could eliminate the global mean bias, it would do so by exacerbating the spatial disagreement in AOD between MODIS and GEOS-Chem.

In the discussion above we consider only sub-micron OM, assuming that no significant $\mathrm{OM}$ mass is present in supermicron mode. Should this assumption be incorrect, it is still unlikely that the low AOD bias in the model could be explained with the addition of coarse OM, as the mass extinction efficiency of these large particles is very low. For example, OM particles with a geometric mean radius of $1 \mu \mathrm{m}$ will have a mass extinction efficiency which is $16 \%$ of the current value. It would therefore take nearly a more than 50 -fold increase in OM mass in the model to reconcile the AOD difference between the model and MODIS.

\section{Conclusions}

This work represents the most comprehensive evaluation of oceanic organic carbon emission inventories to date, by employing aerosol composition measurements obtained from campaigns with wide spatial and temporal coverage. Mean observed $\mathrm{OM}$ concentrations range from $0.07 \mu \mathrm{g} \mathrm{m}^{-3}$ to
$0.77 \mu \mathrm{g} \mathrm{m}^{-3}$. The GEOS-Chem model underestimates observed surface OM when no marine OM source is included, consistent with previous work (Spracklen et al., 2008; Vignati et al., 2010). We find that a marine OM source of 8$9 \mathrm{TgC} \mathrm{yr}^{-1}$ as suggested by both Spracklen et al. (2008) and Langmann et al. (2008), is more than sufficient to account for observed marine OM concentrations, in agreement with the lower end of the range of marine OM source estimates in the literature. We further note that any further increase in OM emissions over the biologically active regions, which would result from including the seasonal size increase of $\mathrm{Vi-}$ gnati et al. (2010), would lead even to larger overestimates of the observed OM concentrations. We find that the schemes developed based on satellite-derived chlorophyll- $a$ concentrations (and wind speed and SST for the Langmann et al. (2008) scheme as implemented here) do not adequately describe the variability in observed OM. This may be attributed to: (1) the inadequate description of chlorophyll- $a$ variability provided by monthly mean satellite maps; (2) the failure to account for the relationship between speciation of phytoplankton associated with chlorophyll- $a$ and OM production; or (3) other unknown drivers for OM production (including secondary sources) not accounted for here.

GEOS-Chem underestimates the mean AOD value for the marine environment in the studied regions (by $21 \%$ ), based on MODIS measurements. Model AOD agrees well with the MAN AOD data based on a limited number of observations. Therefore, it is possible that this underestimate can be partially explained by the uncertainties of satellite retrieval. Inclusion of marine OM in the model does not significantly improve the agreement between measured and simulated AOD. Uncertainties in the marine OM scheme, including size distribution and optical properties, cannot account for this AOD underestimate. Given that (1) the model reproduces (or overestimates) observed mean sulfate concentrations, (2) the GEOS-Chem sea salt representation has recently been optimized to match coarse-mode observations (Sect. 2.1), and (3) the spatial pattern of the bias does not match the distribution of fine mode sea salt, this discrepancy is puzzling. There are considerable uncertainties associated with sea salt emission parameterizations and the meteorological drivers used in models. However, the comparison with satellite AOD suggests that only a parameterization resulting in a very different spatial distribution of sea salt could resolve this discrepancy. This may suggest that either some additional marine source of aerosol has not been accounted for here, or that the observations we have used (ship-based non-refractory composition, satellite AOD and marine in-situ AOD) are insufficient for achieving closure on the marine aerosol budget. Speciated ship-based measurements (including sea-salt), as well as measurements of total $\mathrm{PM}_{1}$ and $\mathrm{PM}_{10}$ mass may be required to resolve this discrepancy. 
Acknowledgements. This work was supported by NASA, grant NNX08AN75G. We thank the MODIS and the SeaWIFS teams for the aerosol and chlorophyll- $a$ products and Jeffrey Reid (NRL) and Jianglong Zhang (University of North Dakota) for providing their quality controlled level-3 MODIS aerosol product. RHaMBLe measurements were supported by the National Environment Research Council (NERC) through the Aerosol Characterisation and Modelling in the Marine Environment (ACMME, NE/E011454/1) and Reactive Halogens in the Marine Boundary Layer (RHaMBLe, NE/D006570/1) projects, both part of the Surface-Ocean/Lower Atmosphere Study (UK SOLAS) directed programme. VOCALS measurements were supported by NSF grant ATM-0744636. OOMPH measurements were supported by the European Union (EU) through the OOMPH project of the EU Sixth Framework Programme and by the Institut Polaire Franais Paul mile Victor (IPEV) through the IPEV-AEROTRACE program. We acknowledge the MAN PIs: Patricia Quinn (USA), Norman Nelson (USA), Joaquim Goes (USA), Andrey Proshutinsky (USA), Andreas Macke (Germany), Sergey Sakerin (Russia), Tim Smyth (UK), Jean Sciare (France), Tymon Zielinski (Poland), Giuseppe Zibordi (Italy), Mike Harvey (New Zealand) and Stuart Piketh (South Africa). We also acknowledge NSF OCE grant 0741818 awarded to P. A. Matrai as part of the VOCALS REx program.

Edited by: E. Vignati

\section{References}

Allan, J., Jimenez, J., Williams, P., Alfarra, M., Bower, K., Jayne, J., Coe, H., and Worsnop, D.: Aerodyne aerosol mass spectrometer. Part 1: Techniques of data interpretation and error analysis, J. Geophys. Res., 108(D3), 4090, doi:10.1029/2002JD002358, 2003.

Allan, J. D., Topping, D. O., Good, N., Irwin, M., Flynn, M., Williams, P. I., Coe, H., Baker, A. R., Martino, M., Niedermeier, N., Wiedensohler, A., Lehmann, S., Mller, K., Herrmann, H., and McFiggans, G.: Composition and properties of atmospheric particles in the eastern Atlantic and impacts on gas phase uptake rates, Atmos. Chem. Phys., 9, 9299-9314, doi:10.5194/acp-99299-2009, 2009.

Alvain, S., Moulin, C., Dandonneau, Y., and Breon, F. M.: Remote sensing of phytoplankton groups in case 1 waters from global SeaWiFS imagery, Deep Sea Res. I, 52, 1989-2004, doi:10.1016/J.DSR.2005.06.015, 2005.

Arnold, S. R., Spracklen, D. V., Williams, J., Yassaa, N., Sciare, J., Bonsang, B., Gros, V., Peeken, I., Lewis, A. C., Alvain, S., and Moulin, C.: Evaluation of the global oceanic isoprene source and its impacts on marine organic carbon aerosol, Atmos. Chem. Phys., 9, 1253-1262, doi:10.5194/acp-9-1253-2009, 2009.

Arnold, S. R., Spracklen, D. V., Gebhardt, S., Custer, T., Williams, J., Peeken, I., and Alvain, S.: Relationships between atmospheric organic compounds and air-mass exposure to marine biology, Environ. Chem., 7, 232-241, doi:10.1071/EN09144, 2010.

Ayers, G.: Comment on regression analysis of air quality data, Atmos. Environ., 35, 2423-2425, 2001.

Bond, T. C., Bhardwaj, E., Dong, R., Jogani, R., Jung, S., Roden, C., Streets, D. G., and Trautmann, N. M.: Historical emissions of black and organic carbon aerosol from energy-related combustion, 1850-2000, Global Biogeochem. Cy., 21, GB2018, doi:10.1029/2006GB002840, 2007.

Canagaratna, M. R., Jayne, J. T., Jimenez, J. L., Allan, J. D., Alfarra, M. R., Zhang, Q., Onasch, T. B., Drewnick, F., Coe, H., Middlebrook, A., Delia, A., Williams, L. R., Trimborn, A. M., Northway, M. J., DeCarlo, P. F., Kolb, C. E., Davidovits, P., and Worsnop, D. R.: Chemical and microphysical characterization of ambient aerosols with the Aerodyne Aerosol Mass Spectrometer, Mass Spectrom. Rev., 26, 185-222, 2007.

Cavalli, F., Facchini, M. C., Decesari, S., Mircea, M., Emblico, L., Fuzzi, S., Ceburnis, D., Yoon, Y. J., O’Dowd, C. D., Putaud, J.-P., and Dell'Acqua, A.: Advances in characterization of size-resolved organic matter in marine aerosol over the North Atlantic, J. Geophys. Res., 109, D24215, doi:10.1029/2004JD005137, 2004.

Cooke, W. F., Liousse, C., Cachier, H., and Feichter, J.: Construction of a $1^{\circ} \times 1^{\circ}$ fossil fuel emission data set for carbonaceous aerosol and implementation and radiative impact in the ECHAM4 model, J. Geophys. Res., 104(D18), 22137-22162, 1999.

DeCarlo, P. F., Slowik, J. G., Worsnop, D. R., Davidovits, P., and Jimenez, J. L.: Particle Morphology and Density Characterization by Combined Mobility and Aerodynamic Diameter Measurements. Part 1: Theory, Aerosol Sci. Tech., 38, 1185-1205, doi:10.1080/027868290903907, 2004.

DeCarlo, P. F., Kimmel, J. R., Trimborn, A., Northway, M. J., Jayne, J. T., Aiken, A. C., Gonin, M., Fuhrer, J. K., Horvath, T., Docherty, K. S., Worsnop, D. R., and Jose, L.: Field-Deployable, High-Resolution, Time-of-Flight Aerosol Mass Spectrometer, Anal. Chem., 78, 8281-8289, doi:10.1021/ac061249n, 2006.

Draper, N. R. and H. Smith: Applied Regression Analysis, 706 pp., John Wiley \& Sons, Inc., 1998.

Drury, E., Jacob, D. J., Spurr, R. J. D., Wang, J., Shinozuka, Y., Anderson, B. E., Clarke, A. D., Dibb, J., McNaughton, C., and Weber, R.: Synthesis of satellite (MODIS), aircraft (ICARTT), and surface (IMPROVE, EPA-AQS, AERONET) aerosol observations over North America to improve MODIS aerosol retrievals and constrain surface aerosol concentrations and sources, J. Geophys. Res., 115, D14204, doi:10.1029/2009JD012629, 2010.

Facchini, M. C., Rinaldi, M., Decesari, S., Carbone, C., Finessi, E., Mircea, M., Fuzzi, S., Ceburnis, D., Flanigan, R., Nilsson, E. D., de Leeuw, G., Martinoetc, M., Woeltjen, J., and O’Dowd, C. D.: Primary submicron marine aerosol dominated by insoluble organic colloids and aggregates, Geophys. Res. Lett., 35, L17814, doi:10.1029/2008GL034210, 2008a.

M. C. Facchini, Decesari, S., Rinaldi, M., Carbone, C., Finessi, E., Mircea, M., Fuzzi, S., Moretti, F., Tagliavini, E., Ceburnis, D., Sciare, J., Kanakidou, M., and O’Dowd, C. D.: Important source of marine secondary organic aerosol from biogenic amines, Environ. Sci. Technol., 42, 9116-9121, 2008b.

Fairlie, T. D., Jacob, D. J., and Park, R. J.: The impact of transpacific transport of mineral dust in the United States, Atmos. Environ., 41, 1251-1266, doi:10.1016/j.atmosenv.2006.09.048, 2007.

Fiorani, L., Okladnikov, I. G., and Palucci, A.: Remote sensing of the southern ocean by MERIS, MODIS, SeaWiFS and ENEA Lidar, J. Optoelectron. Adv. M., 10(6), 1482-1488, 2008.

Frossard, A. A., Shaw, P. M., Russell, L. M., Kroll, J. H., Canagaratna, M. R., Worsnop, D. R., Quinn, P. K., and Bates, T. S.: Springtime Arctic haze contributions of submicron organic particles from European and Asian combustion sources, J. Geophys. 
Res., 116, D05205, doi:10.1029/2010JD015178, 2011.

Fuentes, E., Coe, H., Green, D., de Leeuw, G., and McFiggans, G.: On the impacts of phytoplankton-derived organic matter on the properties of the primary marine aerosol - Part 1: Source fluxes, Atmos. Chem. Phys., 10, 9295-9317, doi:10.5194/acp-10-92952010, 2010.

Gantt, B., Meskhidze, N., and Kamykowski, D.: A new physically-based quantification of marine isoprene and primary organic aerosol emissions, Atmos. Chem. Phys., 9, 4915-4927, doi:10.5194/acp-9-4915-2009, 2009.

Gantt, B., Meskhidze, N., Facchini, M. C., Rinaldi, M., Ceburnis, D., and O'Dowd, C.: Wind speed dependent size-resolved parameterization for the organic enrichment of sea spray, Atmos. Chem. Phys. Discuss., 11, 10525-10555, doi:10.5194/acpd-1110525-2011, 2011.

Gong, S. L.: A parameterization of sea-salt aerosol source function for sub- and super-micron particles, Global Biogeochem. Cy., 17(4), doi:10.1029/2003GB002079, 2003.

Guenther, A., Karl, T., Harley, P., Wiedinmyer, C., Palmer, P. I., and Geron, C.: Estimates of global terrestrial isoprene emissions using MEGAN (Model of Emissions of Gases and Aerosols from Nature), Atmos. Chem. Phys., 6, 3181-3210, doi:10.5194/acp-63181-2006, 2006.

Hawkins, L., Russell, L., Covert, D., Quinn, P., and Bates, T.: Carboxylic acids, sulfates, and organosulfates in processed continental organic aerosol over the Southeast Pacific Ocean during VOCALS-REx 2008, J. Geophys. Res., 115(D13), D13201, doi:10.1029/2009JD013276, 2010.

Heald, C. L., Ridley, D. A., Kreidenweis, S. M., and Drury, E. E.: Satellite observations cap the atmospheric organic aerosol budget, Geophys. Res. Lett., 37, L24808, doi:10.1029/2010GL045095, 2010.

Ito, A. and Kawamiya, M.: Potential impact of ocean ecosystem changes due to global warming on marine organic carbon aerosols, Global Biogeochem. Cy., 24, GB1012, doi:10.1029/2009GB003559, 2010.

Jaeglé, L., Quinn, P. K., Bates, T. S., Alexander, B., and Lin, J.-T.: Global distribution of sea salt aerosols: new constraints from in situ and remote sensing observations, Atmos. Chem. Phys., 11, 3137-3157, doi:10.5194/acp-11-3137-2011, 2011.

Jayne, J. T., Leard, D. C., Zhang, X., Davidovits, P., Smith, K. A., Kolb, C. E., and Worsnop, D. R.: Development of an aerosol mass spectrometer for size and composition analysis of submicron particles, Aerosol Sci. Tech., 33, 49-70, 2000.

Knobelspiesse, K. D., Pietras, C., Fargion, G. S., Wang, M. H., Frouin, R., Miller, M. A., Subramaniam, S., and Balch, W. M.: Maritime aerosol optical thickness measured by handheld sunphotometers, Remote Sens. Environ., 93, 87-106, 2004.

Langmann, B., Scannell, C., and O'Dowd, C.: New directions: Organic matter contribution to marine aerosols and cloud condensation nuclei, Atmos. Environ., 42, 7821-7822, 2008.

Lee, J. D., McFiggans, G., Allan, J. D., Baker, A. R., Ball, S. M., Benton, A. K., Carpenter, L. J., Commane, R., Finley, B. D., Evans, M., Fuentes, E., Furneaux, K., Goddard, A., Good, N., Hamilton, J. F., Heard, D. E., Herrmann, H., Hollingsworth, A., Hopkins, J. R., Ingham, T., Irwin, M., Jones, C. E., Jones, R. L., Keene, W. C., Lawler, M. J., Lehmann, S., Lewis, A. C., Long, M. S., Mahajan, A., Methven, J., Moller, S. J., Mller, K., Müller, T., Niedermeier, N., O’Doherty, S., Oetjen, H., Plane, J.
M. C., Pszenny, A. A. P., Read, K. A., Saiz-Lopez, A., Saltzman, E. S., Sander, R., von Glasow, R., Whalley, L., Wiedensohler, A., and Young, D.: Reactive Halogens in the Marine Boundary Layer (RHaMBLe): the tropical North Atlantic experiments, Atmos. Chem. Phys., 10, 1031-1055, doi:10.5194/acp-10-10312010, 2010.

Levy, R. C., Leptoukh, G. G., Kahn, R., Zubko, V., Gopalan, A., and REMER, L. A.: A Critical Look at Deriving Monthly Aerosol Optical Depth From Satellite Data, IEEE T. Geosci. Remote Sens., 47(8), 2942-2956, doi:10.1109/TGRS.2009.2013842, 2009.

Lewis, E. R. and Schwartz, S. E.: Sea Salt Aerosol Production: Mechanisms, Methods, Measurements, and Models - A Critical Review, Geophysical Monograph Series, Vol. 152, American Geophysical Union, Washington, 2004.

Liao, H., Henze, D. K., Seinfeld, J. H., Wu, S., and Mickley, L. J.: Biogenic secondary organic aerosol over the United States: Comparison of climatological simulations with observations, J. Geophys. Res., 112, D06201, doi:10.1029/2006JD007813, 2007.

Long, M. S., Keene, W. C., Kieber, D. J., Erickson, D. J., and Maring, H.: A sea-state based source function for size- and composition-resolved marine aerosol production, Atmos. Chem. Phys., 11, 1203-1216, doi:10.5194/acp-11-1203-2011, 2011.

Luo, G. and Yu, F.: A numerical evaluation of global oceanic emissions of $\alpha$-pinene and isoprene, Atmos. Chem. Phys., 10, 20072015, doi:10.5194/acp-10-2007-2010, 2010.

Martensson, E. M., Nilsson, E. D., de Leeuw, G., Cohen, L. H., and Hansson, H.-C.: Laboratory simulations and parameterization of the primary marine aerosol production, J. Geophys. Res., 108(D9), 4297-4308, doi:10.1029/2002JD002263, 2003.

Martin, R. V., Jacob, D. J., Chance, K., Kurosu, T. P., Palmer, P. I., and Evans, M. J.: Global inventory of nitrogen oxide emissions constrained by space-based observations of no 2 columns, J. Geophys. Res., 108, 4537, doi:10.1029/2003JD003453, 2003.

Monahan, E. C. and O'Muircheartaigh, I. G.: Whitecaps and the passive remote sensing of the ocean surface, Int. J. Remote Sens., 7(5), 627-642, 1986.

Morys, M., Mims III, F. M., Hagerup, S., Anderson, S. E., Baker, A., Kia, J., and Walkup, T.: Design, calibration, and performance of MICROTOPS II handheld ozone monitor and Sun photometer, J. Geophys. Res., 106, 14573-14582, doi:10.1029/2001JD900103, 2001.

Myriokefalitakis, S., Vignati, E. E., Tsigaridis, K., Papadimas, C., Sciare, J., Mihalopoulos, N., Facchini, M. C., Rinaldi, M., Dentener, F., Ceburnis, D., Hatzianastasiou, N., O’Dowd, C. D., Weele, M. van, and Kanakidou, M.: Modeling of the oceanic source of organic aerosols, Adv. Meteorol., 2010, 939171, doi:10.1155/2010/939171, 2010.

Novakov, T., Corrigan, C. E., Penner, J. E., Chuang, C. C., Rosario, O., and Bracero, O. L. M.: Organic aerosols in the Caribbean trade winds: A natural source?, J. Geophys. Res., 102(D17), 21307-22621, doi:10.1029/97JD01487, 1997.

O’Dowd, C. D., Facchini, M. C., Cavalli, F., Ceburnis, D., Mircea, M., Decesari, S., Fuzzi, S., Yoon, Y. J., and Putaud, J.-P.: Biogenically driven organic contribution to marine aerosol, Nature, 431, 676-680, doi:10.1038/nature02959, 2004.

O’Dowd, C. D., Langmann, B., Varghese, S., Scannell, C., Ceburnis, D., and Facchini, M. C.: A combined organic-inorganic sea-spray source function, Geophys. Res. Lett., 35, L01801, 
doi:10.1029/2007GL030331, 2008.

Olivier, J. and Berdowski, J.: Global emissions sources and sinks, in: The Climate System, vol. 33-78, edited by: Berdowski, J., Guicherit, R. R., and Heij, B., A.A. Balkema Publishers / Swets and Zeitlinger Publishers, Lisse, The Netherlands, 2001.

Ovadnevaite, J., O’Dowd, C., Dall'Osto, M., Ceburnis, D., Worsnop, D. R., and Berresheim, H.: Detecting high contributions of primary organic matter to marine aerosol: A case study, Geophys. Res. Lett., 38, L02807, doi:10.1029/2010GL046083, 2011.

Palmer, P. I. and Shaw, S. L.: Quantifying global marine isoprene fluxes using MODIS chlorophyll observations, Geophys. Res. Lett., 32, L09805, doi:10.1029/2005GL022592, 2005.

Park, R. J., Jacob, D. J., Chin, M., and Martin, R. V.: Sources of carbonaceous aerosols over the United States and implications for natural visibility, J. Geophys. Res., 108(D12), 4355, doi:10.1029/2002JD003190, 2003.

Park, R. J., Jacob, D. J., Field, B. D., Yantosca, R. M., and Chin, M.: Natural and transboundary pollution influences on sulfatenitrate-ammonium aerosols in the United States: Implications for policy, J. Geophys. Res., 109, doi:10.1029/2003JD004473, 2004.

Pierce, J. R. and Adams, P. J.: Global evaluation of CCN formation by direct emission of sea salt and growth of ultrafine sea salt, J. Geophys. Res., 111, D06203, doi:10.1029/2005JD006186, 2006.

Remer, L. A., Kleidman, R. G., Levy, R. C., Kaufman, Y. J. , Tanre, D., Mattoo, S., Martins, J. V., Ichoku, C., Koren, I., Yu, H., and Holben, B. N.: Global aerosol climatology from the MODIS satellite sensors, J. Geophys. Res., 113, D14S07, doi:10.1029/2007JD009661, 2008.

Roelofs, G. J.: A GCM study of organic matter in marine aerosol and its potential contribution to cloud drop activation, Atmos. Chem. Phys., 8, 709-719, doi:10.5194/acp-8-709-2008, 2008.

Russell, L. M., Hawkins, L. N., Frossard, A. A., Quinn, P. K., and Bates, T. S.: Carbohydrate-like composition of submicron atmospheric particles and their production from ocean bubble bursting, P. Natl. Acad. Sci., 107(15), 6652-6657, doi:10.1073/pnas.0908905107, 2010.

Sciare, J., Favez, O., Sarda-Estev̀e, R., Oikonomou, K., Cachier, H., and Kazan, V.: Long-term observations of carbonaceous aerosols in the Austral Ocean atmosphere: Evidence of a biogenic marine organic source, J. Geophys. Res., 114, D15302, doi:10.1029/2009JD011998, 2009.

Shindell, D. T., Chin, M., Dentener, F., Doherty, R. M., Faluvegi, G., Fiore, A. M., Hess, P., Koch, D. M., MacKenzie, I. A., Sanderson, M. G., Schultz, M. G., Schulz, M., Stevenson, D. S., Teich, H., Textor, C., Wild, O., Bergmann, D. J., Bey, I., Bian, H., Cuvelier, C., Duncan, B. N., Folberth, G., Horowitz, L. W., Jonson, J., Kaminski, J. W., Marmer, E., Park, R., Pringle, K. J., Schroeder, S., Szopa, S., Takemura, T., Zeng, G., Keating, T. J., and Zuber, A.: A multi-model assessment of pollution transport to the Arctic, Atmos. Chem. Phys., 8, 5353-5372, doi:10.5194/acp-8-5353-2008, 2008.

Sinreich, R., Coburn, S., Dix, B., and Volkamer, R.: Ship-based detection of glyoxal over the remote tropical Pacific Ocean, Atmos. Chem. Phys., 10, 11359-11371, doi:10.5194/acp-1011359-2010, 2010.

Smirnov, A., Holben, B. N., Kaufman, Y. J., Dubovik, O., Eck, T. F., Slutsker, I., Pietras, C., and Halthore, R. N.: Optical properties of atmospheric aerosol in maritime environments, J. At- mos. Sci., 59, 501-523, 2002.

Smirnov, A., Holben, B. N., Slutsker, I., Giles, D., McClain, C. R. , Eck, T. F., Sakerin, S. M., Macke, A., Croot, P., Zibordi, G. , Quinn, P. K., Sciare, J., Kinne, S., Harvey, M., Smyth, T. J. , Piketh, S., Zielinski, T., Proshutinsky, A., Goes, J. I., Nelson, N. B., Larouche, P., Radionov, V. F., Goloub, P.,Moorthy, K. K., Matarrese, R., Robertson, E. J., and Jourdin, F.: Maritime Aerosol Network as a component of Aerosol Robotic Network, J. Geophys. Res., 114, D06204, doi:10.1029/2008JD011257, 2009.

Smirnov, A., Holben, B. N., Giles, D. M., Slutsker, I., O’Neill, N. T., Eck, T. F., Macke, A., Croot, P., Courcoux, Y., Sakerin, S. M., Smyth, T. J., Zielinski, T., Zibordi, G., Goes, J. I., Harvey, M. J., Quinn, P. K., Nelson, N. B., Radionov, V. F., Duarte, C. M., Losno, R., Sciare, J., Voss, K. J., Kinne, S., Nalli, N. R., Joseph, E., Krishna Moorthy, K., Covert, D. S., Gulev, S. K., Milinevsky, G., Larouche, P., Belanger, S., Horne, E., Chin, M., Remer, L. A., Kahn, R. A., Reid, J. S., Schulz, M., Heald, C. L., Zhang, J., Lapina, K., Kleidman, R. G., Griesfeller, J., Gaitley, B. J., Tan, Q., and Diehl, T. L.: Maritime aerosol network as a component of AERONET - first results and comparison with global aerosol models and satellite retrievals, Atmos. Meas. Tech., 4, 583-597, doi:10.5194/amt-4-583-2011, 2011.

Spracklen, D. V., Arnold, S. R., Sciare, J., Carslaw, K. S., and Pio, C.: Globally significant oceanic source of organic carbon aerosol, Geophys. Res. Lett., 35, L12811, doi:10.1029/2008GL033359, 2008.

Tegen, I. and Lacis, A. A.: Modeling of particle size distribution and its influence on the radiative properties of mineral dust aerosol, J. Geophys. Res., 101(D14), 19237-19244, 1996.

Turpin, B. J. and Lim, H. J.: Species contributions to PM2.5 mass concentrations: Revisiting common assumptions for estimating organic mass, Aerosol Sci. Technol., 35(1), 602-610, 2001.

van der Werf, G. R., Randerson, J. T., Giglio, L., Collatz, G. J., Kasibhatla, P. S., and Arellano Jr., A. F.: Interannual variability in global biomass burning emissions from 1997 to 2004, Atmos. Chem. Phys., 6, 3423-3441, doi:10.5194/acp-6-3423-2006, 2006.

Vignati, E., Facchini, M. C., Rinaldi, M., Scannell, C., Ceburnis, D., Sciare, J., Kanakidou, M., Myriokefalitakis, S., Dentener, F., and O'Dowd, C. D.: Global scale emission and distribution of sea-spray aerosol: Sea-salt and organic enrichment, Atmos. Environ., 44, 670-677, 2010.

Yassaa, N., Peeken, I., Zollner, E., Bluhm, K., Arnold, S., Spracklen, D., and Williams, J.: Evidence for marine production of monoterpenes, Environ. Chem., 5, 391-401, doi:10.1071/EN08047, 2008.

Yevich, R. and Logan, J. A.: An assesment of biofuel use and burning of agricultural waste in the developing world, Global Biogeochem. Cy., 17(4), 1095, doi:10.1029/2002GB001952, 2003.

Yoon, Y. J., Ceburnis, D., Cavalli, F., Jourdan, O., Putaud, J. P., Facchini, M. C., Decesari, S., Fuzzi, S., Sellegr, K., Jennings, S. G., and O'Dowd, C. D.: Seasonal characteristics of the physicochemical properties of North Atlantic marine atmospheric aerosols, J. Geophys. Res., 112, D04206, doi:10.1029/2005JD007044, 2007.

Zhang, C., Hu, C., Shang, S., Müller-Karger, F. E., Li, Y., Dai, M., Huang, B., Ning, X., and Hong, H.: Bridging between SeaWiFS and MODIS for continuity of chlorophyll- $a$ concentration assessments off Southeastern China, Remote Sens. Environ., 
102(3-4), 250-263, doi:10.1016/j.rse.2006.02.015, 2006.

Zhang, J. and Reid, J. S.: MODIS aerosol product analysis for data assimilation: Assessment of over-ocean level 2 aerosol optical thickness retrievals, J. Geophys. Res., 111, D22207, doi:10.1029/2005JD006898, 2006.

Zhang, J., Reid, J. S., and Holben, B. N.: An analysis of potential cloud artifacts in MODIS over ocean aerosol thickness products, Geophys. Res. Lett., 32, L15803, doi:10.1029/2005GL023254, 2005.
Zorn, S. R., Drewnick, F., Schott, M., Hoffmann, T., and Borrmann, S.: Characterization of the South Atlantic marine boundary layer aerosol using an aerodyne aerosol mass spectrometer, Atmos. Chem. Phys., 8, 4711-4728, doi:10.5194/acp-8-47112008, 2008. 